\title{
The Effectiveness of Business Development Services Providers (BDS) in Improving Access to Debt Finance by Start-Up SMEs in South Africa
}

\author{
Musara Mazanai \\ Department of Business Management, University of Fort Hare \\ University of Fort Hare, Alice, P.B. X1314, Eastern Cape, 5700, South Africa \\ E-mail: jilgram@yahoo.com \\ Olawale Fatoki (Corresponding author) \\ Department of Business Management, University of Fort Hare \\ University of Fort Hare, Alice, P.B. X1314, Eastern Cape, 5700, South Africa \\ Tel: 927-40-653-2248Ｅ-mail: ofatoki@ufh.ac.za
}

Received: February 6, 2011

Accepted: February 21, 2011

doi:10.5539/ijef.v3n4p208

\begin{abstract}
Start-up SMEs are very important to employment creation, poverty alleviation and sustainable economic development of South Africa. One of the challenges facing start-ups is non-availability of debt financing. The government of South Africa has put in place various intervention efforts to improve access to debt finance by start-up SMEs. This study investigates empirically the effectiveness of Business Development Services providers (BDSs) in improving access to finance by start-up SMEs. Data was collected through the use of self-administered questionnaire. Data analysis included descriptive statistics, correlation and regression analysis. The results indicate that most start-up SMEs are not aware of the programme. The results furthermore indicate that start-up SMEs that are aware and use the programme have improved access to debt finance. The recommendations focused on improving the awareness of the programme by start-up SMEs.
\end{abstract}

Keywords: Business Development Services, debt finance, Start-up SMEs

\section{Introduction}

Small and medium sized enterprises (SMEs) play a significant role in the economic development of every nation, particularly in developing countries like South Africa (refer to table 1 for the quantitative definition of SMEs in South Africa). The development of SMEs is seen globally, as a key strategy for economic growth, job generation and poverty reduction (Berry, Blottnitz, Cassim, Kesper, Rajaratnam and Seventer, 2002). The South African Department of Trade and Industry (DTI) estimates that small businesses employ almost half of formally employed persons, and contribute to $42 \%$ of the country's gross domestic product (Makgoe, 2008). Start-up SMEs are a key driver of sustainable economic development of the country. Gree and Thurnik (2003) argue that the contribution of the SME sector cannot be sustained without the creation of new SMEs. According to Maas and Herrington (2006) start-up SMEs are seen as a significant component of the solution to South Africa's development issues. Without start-up SMEs, South Africa risks economic stagnation. Start-ups SMEs are firms that have been in operation for a period of time less than 3.5 years (Maas and Herrington, 2006).

Despite the importance of the creation and survival of start-up SMEs to the South African economy, $75 \%$ of start-up SMEs created in South Africa fail within the first two years of operation. Von Broembsen, Wood and Herrington (2005) state that the probability of a new SME surviving beyond 42 months and becoming an established firm is less likely in South Africa than in any other Global Entrepreneurship Monitor sampled country. Various challenges and impediments prevent the creation of new SMEs as well as cause the high failure rates of new SMEs in South Africa. One of these is the non-availability of formal sector financing. According to Maas and Herrington (2006) and Herrington et al. (2009) access to finance is a major problem for the South African entrepreneur. Lack of financial support is the second most reported contributor to low new firm creation and failure, after education and training, in South Africa. FinMark Trust (2006) provides evidence that only 2\% of start-up SMEs in South Africa are able to access bank loans. Foxcroft, Wood, Kew, Herrington and Segal (2002) report that $75 \%$ of applications for bank credit by new SMEs in South Africa is rejected. 
Rogerson (2008) points out that there is a market failure in addressing the financial needs of start-up SMEs. Schoombee (2000) argue that the reasons for market failure are explained in terms of the high risk of default when banks grant credit, high cost of screening, low returns and the particular issues of dealing with informal sector entrepreneurs due to language and cultural barriers. Therefore, there is need for government intervention to assist start-up SMEs in meeting their financial needs. Ensuring access to finance has been an important pillar of public support for small business (Craig, Jackson and Thomson, 2007). From this perspective government intervention to assist SMEs could help to create employment and alleviate poverty in South Africa (Alweendo, 2004).

The government of South Africa, through the Department of Trade and Industries (DTI) has established a number of public sector institutions that caters for the needs of SMEs. Among them are Khula Enterprise Finance Ltd, Small Enterprises Development Agency (SEDA), Industrial Development Cooperation (IDC), Umsobomvu Youth Fund (UYF), South African Micro-Finance Apex Fund (SAMAF), National Empowerment Fund (NEF), South African Women Entrepreneurs' Network (SAWEN) and Technology for Women in Business (TWIB) (Department of Trade and Industries, 2005). Provincial government agencies such as the Eastern Cape Development Corporation (ECDC) in the Eastern Cape, Gauteng Enterprise Propeller (GEP) in Gauteng, Limpopo Business Support Agency (LIBSA) in Limpopo, and the Western Cape's Red Door also provide a range of business-development services to SMMEs at provincial level and have strengthened partnerships with SEDA. These organisations are termed Business Development Services providers (BDSs).

The Committee of Donor Agencies for Small Enterprise Development, (2001) defines BDS as services that improve the performance of the enterprise, its access to markets, and its ability to compete. The definition of BDS, “... includes an array of business services (such as training, consultancy, marketing, information, technology development and transfer, business linkage promotion, etc.), both strategic (medium to long term issues that improve performance] and operational [day-to-day issues)". BDS are designed to serve individual businesses, as opposed to the larger business community. The International Finance Corporation (IFC) (2006) defines Business Development Services as “...those non-financial services and products offered to entrepreneurs at various stages of their business needs. IFC adds that though BDS do not provide collateral and guarantees to start-up SMEs, however, they can provide information to start-up SMEs about where to obtain guarantees for funding.

Despite a wide range of BDSs in the South African business landscape, start-up SMEs still experience difficulties accessing finance and still suffer from a high failure rate thereby hampering entrepreneurial development. The question is "are Business Development Service providers effective in addressing access to finance challenges facing SMEs? Effectiveness will be measured in three ways (1) awareness of BDS by start-up SMEs (2) use of BDS by start-up SMEs (3) improved access to debt finance by start-up SMEs that use BDS.

\section{The research objectives}

- To investigate if start-up SMEs are aware of BDS

- To investigate if start-up SMEs that are aware of BDS use the service

- To investigate whether start-up SMEs that use BDS have improved access to debt finance

\section{Literature review}

\subsection{Theoretical construct}

Capital structure is described as the mix of debt and equity that a firm uses to finance its operations (Gitman, 2003). The theoretical principles underlying capital structure can generally be described in terms of the static trade-off theory by Modigliani and Miller $(1958,1963)$ the agency theory by Jensen \& Meckling (1976) and extended by Stiglitz and Weiss (1981) and the pecking order theory by Myers (1984). Modigliani and Miller (1963) argue that because the interest on debt is tax-deductible, thereby creating tax savings for the borrower, it becomes possible for firms to minimize their costs of capital and maximize shareholders' wealth by using debt. The tax advantage of debt makes it cheaper than equity. The mix of cheap debt with relatively expensive equity reduces a firm's cost of capital, which is the cut-off rate for investment acceptance decisions. This is known as the leverage effect of debt. According to Miller and Modigliani (1963) a firm should have 100\% debt in its capital structure. This way the firm can take absolute advantage of the tax-shield. Scott (1972) and Kraus and Litzenberger (1973) point out that theoretically $100 \%$ tax shield does not exist in reality because of distress costs. Debt leads to a legal obligation to pay interests and principal. If a firm cannot meet its debt obligations it is forced into bankruptcy and incurs associated costs.

Myers (1984) alludes in the pecking order theory that there is no well-defined optimal capital structure; instead the debt ratio is the result of hierarchical financing over time. Management has a preference to choose internal financing before external financing. When a firm is forced to use external financing sources, managers select the least risky and demanding source first. When it is necessary to issue external sources, debt issuance is preferred to new equity. 
Carpenter and Petersen (2002) find that the growth of start-up SMEs is constrained by dependence on internal finance. In contrast, firms that make use of external funds exhibit growth rates far above what can be supported by internal finance. This implies that internal finance is often inadequate for growing SMEs. According to Demirguc-Kunt, Maksimovic, Beck and Laeven, (2006) the two primary sources of external finance for start-up SMEs are equity and debt. Shane (2008) contends that access to external equity is very limited for start-up SMEs. The inadequacy of internal capital and the lack of external equity make many new SMEs dependent on bank loans and overdrafts for early-stage financing. Despite the dependence of start-up SMEs on debt finance, paradoxically access to debt finance is very limited for new SMEs, especially in developing countries. Commercial banks hesitate to lend to start-up SMEs. Stiglitz and Weiss (1981) refer to this phenomenon as capital rationing.

Stiglitz and Weiss (1981) argue that it could be rational for credit providers to engage in credit rationing due to problems of asymmetric information and agency problems. Asymmetric information is prevalent if a firm knows the expected risk and return of their project, while the credit provider only knows the average expected return and risk of an average project in the economy. Agency problem implies that bank managers are agents of shareholders and granting of credit should always ensure that interests of shareholders are not compromised. Credit markets also diverge from an idealized market because information is imperfect. A lender's willingness to lend money to a particular borrower may hinge on having enough information about the borrower's reliability and on being sure that the borrower will use the borrowed funds effectively. The absence of good information may explain why lenders choose not to serve certain borrowers, such start-up SMEs. The Stiglitz and Weiss's model argues for government intervention on the grounds of an explicit account of market failure. This implies that if credit rationing significantly affects small business credit markets, a rationale exists for supporting small enterprises through government programs aimed at improving their access to credit.

\subsection{Empirical review}

Rogerson (2008) points out that the role of private banks in addressing the credit needs of SMEs is a major area for concern for policy makers. Schoombee (2000) argue that the failure of commercial banks to serve the low-income market makes government intervention necessary. Initiatives by banks to enter the market have centered largely on the formally employed and/or delivering products to established rather than emerging SMEs (Daniels 2004). The reasons for market failure are explained in terms of the high risk of default when banks grant credit, high cost of screening and low returns (Schoombee 2000). In South Africa constrained access to finance for start-up SMEs is a cause of concern. According to Umsobomvu Youth Fund (2008) only about two out of every ten applications for credit by start-up SMEs are approved. There appears to be failures in the financial sector to provide impressive access to finance for SMEs in South Africa. Therefore, there is need for government intervention to assist SMEs.

Brijlal, (2008) suggests that BDS is primarily an activist function, seeking to both address market failure by proviing information required by businesses, providing or facilitating the provision of consultancy services, providing or encouraging skills and business training; and to improve equity by engaging in technology transfer and development, and providing subsidized access to infrastructure and financial services. Park, Lim and Koo (2008) justify that market imperfections as a strong justification for the need to provide government support to the SME sector, who despite their significant contribution to socio-economic growth finds it difficult to survive competition with large and established enterprises. Leaving the SME sector without government or donor support can increasingly jeopardise their growth and survival, therefore there is need for government intervention.

Green (2003) however argue that credit guarantee and other government intervention schemes are a failure and there is no sufficient reason for government intervention by means of publicly-funded schemes and question the cost-effectiveness of such schemes. Green (2003) points out that, the main argument advanced by government officials in favour of government intervention is the assertion that small businesses are faced with a systematic lack of finance and that the economy in general would benefit from increased small-firm access to credit. Green (2003) further notes that there is no clear justification of the underlying reasons for the need for government intervention. Instead, to address the problem of asymmetric information and to reduce the transaction costs as well as the uncertainty surrounding repeat lending, credit bureaus are seen as superior to government intervention schemes.

Hitchins (2002) presents a rigorous critic of government intervention in markets. Hitchins (2002) argue that government intervention has often been ineffective because: It has not been based on a sound analysis of market failures; It does not address specific market failures; It ignores market signals in trying to achieve objectives; It underestimates the information needed for effective interventions; It overlooks the limited capacities, competencies and capabilities of the government; It overestimates the human and other resources available; and it disregards efficiency, scale and other considerations. 
Green (2003) concludes that government intervention in the form of public sector intervention alone is not sufficient. There is need to include the more efficient private sector in the loop towards creating a mix of a market driven and social orientation towards sustainable support provision to the SME sector (Green, 2003). Despite, several arguments against government intervention in BDS, a mix of private sector and public sector services provision is of critical importance. However, their effectiveness and efficiency, collectively needs to be investigated. More importantly, addressing access to finance challenges facing start-up SMEs requires collective efforts by the government and the private sector.

Hitchins (2002) reveals that incidences of government intervention are notable through BDS provision. Therefore, the role in markets and effectiveness of BDS in addressing problems faced by start-up SMEs need to investigated. This suggests that there is a need to integrate government interventions with market forces and the provision of BDS should be strategically rethought to ensure effective service delivery. It can be implied that with problems in the market and high failure rates of start-up SMEs in South Africa, government intervention in the form of BDS is a good step towards improving the success of start-up SMEs. Furthermore in accordance with the international best practice government intervention is necessary to improve the availability of financial resources to start-up SMEs.

Orford, Herrington and Wood (2004) declare that the government of South Africa has invested considerable resources into supporting small enterprises. Despite a wide range of BDSs in the South African business landscape, start-up SMEs are still experiencing daunting challenges, specifically on access to finance, hampering entrepreneurial development (Rogerson, 2008). It is therefore important to assess the effectiveness of BDSs in addressing access to finance challenges facing start-up SMEs.

\section{Research Methodology}

The empirical study was approached from the perspective of a formal research design through the definition of the study population, the incorporation of suitable measuring instrument and reliable techniques for data analysis as stipulated in Cooper and Schindler (2008). The empirical research for the study was conducted in two ways; a pilot study and the main survey. Self-administered questionnaires were used for data collection in a survey. The research questionnaire was divided into three main parts: Section 1 addressed the challenges facing start-up SMEs in accessing external finance. Section 2 addressed the issue of awareness, use and effectiveness of BDSs in improving access to external finance for start-up SMEs. Section 3 focused on business characteristics and demographic factors. Following the design of the initial questionnaire, a pilot study on 20 respondents was conducted. The result of the pilot study and a discussion with a panel of experts led to the initial questionnaire being revised accordingly taking into consideration all the flaws identified in the process. The Buffalo City Municipality was the study area. The municipality consists of East London (including Mdantsane), King William's Town and Bisho. The study population in this study was obtained from information provided by the Small Businesses Development Agency (SEDA), the Black Enterprises register and Yellow Page telephone directory. According to these sources, 407 SMEs suited the definition of start-up SMEs in the area of focus for this study (that is, SMEs that had been in operation for a period of less than 42 months). The study used the probability sampling method. The sample size was calculated using the Raosoft sample size calculator using a margin of error of 5\%, 95 confidence levels and a 50\% response distribution (Raosoft, 2010). The sample size calculator gave a minimum recommended sample size of 198 SMEs. However, 315 questionnaires were distributed to provide for non-responses. The sample is small enough to allow for the feasibility of the study and yet large enough to be a true representative of the targeted population. Data analysis was done using the Statistical Package for Social Sciences. Statistical analysis included descriptive statistics, Pearson correlation and regression analysis. Reliability and validity were ensured by pre-testing the research instrument in a pilot study, using a panel of experts in the field of management to evaluate the research instrument for conceptual clarity and comprehensively reviewing the literature for theoretical constructs and empirical conclusions. The Kolmogorov-Smirnov test was used to determine the normality of the data. Case wise deletion method was used to treat missing values.

\section{Results and discussions}

\subsection{Response rate and demographics}

The population for this study was all start-up that had been in operation for a period of less than 42 months. Of the 315 questionnaires distributed to respondents, 207 were returned achieving a response rate of $65.7 \%, 49 \%$ of the respondents were close corporations, $38 \%$ were sole traders, $11 \%$ were partnerships and only $2 \%$ were Private companies (Pty Ltd). This indicates that the most common form of business ownership in the Buffalo City municipality are close corporations followed by sole traders, then partnerships and the least common are Private companies. Most of the respondent businesses were at least three years old (44.5\%) and 30\% were at most two years old while the rest were in their third year. The results indicate that $73 \%$ of these businesses had at most 50 employees and only $2.4 \%$ had at least 150 employees. About $71 \%$ of the businesses had at most five members and 
only $2.9 \%$ had more than 16 but less than 20 members. Results show that $79 \%$ of the people who completed the questionnaire of behalf of the business were the owners while $21 \%$ were the appointed managers. About $76.5 \%$ were at most 45 years old and $35 \%$ had at least a post matric diploma and $10 \%$ had at first degree and the rest were matric certificate holders.

\subsection{Access to finance challenge}

One of the purposes of the study was to solicit responses on the perceptions of start-up SMEs about the challenges they face in attempting to access external debt finance. Results showed that 184 respondents (89\%) agreed that access to debt finance is a major challenge facing start-up SMEs.

\subsection{Awareness of BDS}

The results on awareness indicate that 141 respondents $(68 \%)$ were not aware of the existence of BDS providers in their localities. Only 66 respondents (32\%) showed that they are of BDS providers in their localities. Therefore from the findings, the majority of the respondents lack awareness of BDS providers operating in the localities.

\subsection{Relationship between non-awareness and access to debt finance}

A correlation analysis was done to investigate the relationship between non-awareness of BDS and success in getting access to finance and awareness of BDS and success in getting access to finance.

\section{Insert table 2 here}

The results showed a statistically significant negative correlation between non-awareness of BDS and success in getting financing $(r=-0.546, p=0.0024)$. This indicates that non-awareness of BDS is negatively correlated with success in getting access to finance.

\section{Insert table 3 here}

Awareness of BDS has significant effects on the responses to success in access to finance. This is shown by the regression results in Table 3 . The beta coefficient $(0.921)$ that is significantly different from zero. This indicates that with every unit increase in awareness of BDS, the chances of getting access to finance increase by 0.921 . These effects have p-values that are less than 0.05 , which suggests high statistical significance.

\subsection{Use of BDS by start-up SMEs}

The results of the study indicated that of the 66 respondents who indicate that they aware of BDS providers in their localities, 58 respondents ( $88 \%$ ) have actually made use of the services of BDS and 8 respondents $(12) \%$ of the respondents have not used the services of BDS. The results further revealed that some respondents have used more than one BDS providers. The majority of the respondents (82\%) indicated that they have used the services of National Youth Development Agency (NYDA) followed by Small Enterprises Development Agency (SEDA) (73\%), Eastern Cape Development Corporation (ECDC) (56\%) and other (12\%). The BDS services used by start-up SMEs are: business planning (79\%) and business registration (63\%) stand out as the mostly used services of BDS by the respondents. The other services were information sharing and networking (3\%), feasibility assessments (62\%), business and financial administration (12.2\%), mentorship services (23\%), training services $(67.2 \%)$ and marketing and marketing planning (52\%).

\subsection{Relationship between the use of BDS and access to debt finance}

Correlation and regression analyses were used to investigate the relationship between the use of BDS and success in getting access to finance and non-use of BDS and success in getting access to finance.

\section{Insert tables 4 and 5 here}

The results showed a statistically significant negative correlation between non-use of BDS and success in getting financing $(r=-0.346, p=0.0124)$. This indicates that non-use of BDS is negatively correlated with success in getting access to finance. In contrast, a correlation analysis between use of BDS and success in getting access to finance showed a statistically significant strong correlation between awareness of BDS and success in getting access to finance ( $\mathrm{r}=0.841, \mathrm{p}=>0.0021)$. The result of the regression model showed an $83 \%$ variations in responses to access to finance outcome (adjusted R-square $=0.830)$ are explained by use of BDS. The F-test $(\mathrm{F}=0.356, \mathrm{p}<0.000)$ is significant indicating that the model as a whole accounts for significant variations on the use of BDS and access to finance. The results of the regression analysis further confirm that the use of BDS has a significant positive impact on access to finance. These are shown by the beta coefficient of 0.973 . The results are interpreted to mean that with a unit increase in use of BDS chances of succeeding in getting financing increases by 0.973 . These effects have $\mathrm{p}$-values that are less than 0.05 ( $\mathrm{p}$-value $=0.001$ ), which suggests high statistical significance.

\section{Managerial implications and recommendations}

Stiglitz and Weiss (1981) developed the main theoretical contributions about credit rationing and suggest that the problems of information asymmetry, moral hazard and adverse selection have the greatest limitations on productive 
credit granting. The arguments put forward by Stiglitz and Weiss (1981) is that in the situation of market failure, there is the need for government intervention to help the SME sector overcome the challenge of weak access to debt finance. The results of this study indicate that most start-up SMEs are not aware of BDS. However, start-up SMEs that are aware and use BDS have improved access to debt finance. This implies that BDS is effective in improving access to finance but the fact that the majority of start-up SMEs are not aware of the service is a major limitation of the effectiveness of BDS.

Thus it is recommended the central government should work hand in hand with private sector institutions to ensure effective and adequate access to finance by start-up SMEs. This can be done through efficient and effective provision of BDS. Such initiatives as BDS provision can be intensified through intensive awareness campaigns to encourage the use of BDS by start-up SMEs. Awareness campaigns can be undertaken by the BDS providers through aggressive campaign in the print and electronic media. Commercial banks can also help create awareness of BDS by informing start-ups that apply for credit of the existence of BDS. The websites of the major banks should include this information. Commercial bank branches too should have leaflets to inform start-ups about the existence of BDS. Trade associations can also be used to inform SMEs about the existence of BDS. It is important for start-ups to join trade associations to be aware of information about government assistance.

Furthermore, emanating from the harsh realities of getting external financing and market failures, start-up SMEs should do a thorough groundwork to ensure self-sustainability of their business until they reach establishment stages. It is important for the owners of start-up SMEs to get investment ready. This implies that they have to take responsibility for their personal development. SME owners should go for training on business planning, financial management and entrepreneurship if they want to access external finance. Depending on the government to provide all the assistance is in the long-run not sustainable.

\section{Limitations of the study and future research direction}

Addressing challenges facing SMEs can be approached from different perspectives. Despite numerous challenges impeding the survival and growth of start-up SMEs, the study focused mainly on the major problem, access to finance. Only BDSs were investigated as an intervention to address access to finance challenges facing start-up SMEs. In addition, the study was limited to the opinions of start-up owners (i.e. the demand side). Another study could examine the effectiveness and problems faced by BDS providers (i.e. the supply side) owner-managers and managers.

\section{References}

Alweendo, T. (2004). Keynote address at the Opening Ceremony of the 6th African Development Finance Conference \& SMME awards, Cape Town, South Africa (20-21 October, 2004). [Online]. Available: https://www.bon.com.na/docs/spr/keynote $\% 20$ address $\% 20$ by $\%$ the $\% 20$ Governor $\% 20$ at $\% 20$ the $\% 20$ Opening $\% 20$ Cer emony $\% 20$ of $\% 206^{\text {th }} \% 20$ Africa $\% 20$ Development $\% 20$ Finance $\% 20$ Conference $\% 20 \& \% 20$ SMME $\% 20$ awards.pdf [May15, 2010].

Berry, A., Blottnitz, M., Cassim, R., Kesper, A., Rajaratnam B. \& Seventer, D. E. (2002). The Economics Of Smmes in South Africa. [Online] Available: http://www.tips.org.za/506.pdf [June 23, 2010].

Brijlal, P. (2008). Business Development Service: Addressing the Gap In The Western Cape, South Africa. International Business \& Economics Research Journal, 7(9), 49-56.

The Committee of Donor Agencies for Small Enterprise Development. (2001). Business Development Services for Small Enterprises: Guiding Principles for Donor Intervention. [Online] Available: www.enterprise-development.org/download.aspx?id=163 [May 22, 2010].

Cooper, D. R. \& Schindler, P. S. (2008). Business Research Methods, $10^{\text {th }}$ Edition, Boston: McGraw-Hill Irwin.

Craig, B. R., Jackson, W. E. \& Thompson, J. B. (2007). Does Government Intervention in the Small-Firm Credit Market Help Economic Performance? Policy Discussion Papers No. 22: Federal Reserve Bank of Cleveland.

Department of Trade and Industry (DTI), (2005). Integrated Small Enterprise Development Strategy: Unlocking the Potential of South African Entrepreneurs. Pretoria: DTI.

Daniels, R. (2004). Financial intermediation, regulation and the formal microcredit sector in South Africa. Development Southern Africa, 21(5), 831-850. doi:10.1080/0376835042000325732, http://dx.doi.org/10.1080/0376835042000325732

Demirguc-Kunt, A., Maksimovic, V., Beck, T. \& Laeven, L. (2006). The determinant of financing obstacles. International Journal of Money and Finance, 25(6), 932-952. doi:10.1016/j.jimonfin.2006.07.005, http://dx.doi.org/10.1016/j.jimonfin.2006.07.005 
FinMark Trust. (2006). Fin scope small business survey report. [online]. Available: http://www.finmarktrust.org.za [May 18, 2010].

Foxcroft, M., Wood, E., Kew, J., Herrington, M. \& Segal. N. (2002). Global entrepreneurship monitor South African report. [online] Available: http://www.gbs.nct.ac.za/gbswebb/userfiles/gemsouthafrica2000pdf [October $18,2010]$

Gitman, L.J. (2003). The Principles of Managerial Finance. New York: Pearson Education Inc.

Government Gazette of the Republic of South Africa. (2003). National Small Business Amendment Act. [Online]. Available: http://www.info.gov.za/gazette/acts/2003/a26-03.pdf [June 15, 2009].

Gree, A. \& Thurnik, C. (2003). Firm selection and industry evolution: the post country performance of new firm. Journal of Evolutionary Economics, 4 (4), 243-264.

Green, A. (2003). Credit Guarentee Schemes for Small Enterprises: An Effective Instrument to Promote Private Sector-led Growth? SME Technical Working Paper No 10.Viena: UNIDO. [Online] Available: http://www.unido.org/file-storage/download/?fileid=18223 [February 23, 2010].

Herrington, M., Kew, J. \& Kew, P. (2009). Global Entrepreneurship Monitor, South African report. [Online] Available: http://www.gbs.nct.ac.za/gbswebb/userfiles/gemsouthafrica2000pdf [October 15, 2010].

Hitchins, R. (2002). The role of the government in BDS market: a preliminary review for the international labour office (SEED) [Online] Available: www.bdsknowledge.org/dyn/bds/docs/174/Ros\%20BDS\%RH.pdf [June 12, 2010].

International Finance Corporation (IFC). (2006). A dianostic study on Access to Finance for women entrepreneurs. [Online]. Available: www.ifc.org/...Access FinanceSA.../IFCGEM+Brochure+sec+1-2.pdf. [November 20, 2010].

Jensen, M.C. \& Meckling W.H. (1976). Theory of the firm: managerial behaviour, agency cost and ownership structure. Journal of financial Economics, 3(4), 305-360. doi:10.1016/0304-405X(76)90026-X, http://dx.doi.org/10.1016/0304-405X(76)90026-X

Kraus, A. \& Litzenberger, R.H. (1973). A state-preference model of optimal financial leverage. Journal of Finance, 9(1), 911-922. doi:10.2307/2978343, http://dx.doi.org/10.2307/2978343

Maas, G. \& Herrington, M. (2006). Global Entrepreneurship Monitor: South African Report 2006. The UCT Centre for Innovation and Entrepreneurship. [Online] Available: http://www.gemconsortium.org/document.aspx?id756 [June 6, 2010].

Makgoe P. (2008). Government procurement policy and SMME development successes and challenges. University of Free State. South Africa.

Modigliani, F. \& Miller, M.H. (1958). The cost of capital, corporation finance and the theory of investment. American Economic Review, 48(3), 261-295.

Modigliani, F. \& Miller, M.H. (1963). Corporate income taxes and the cost of capital: A correction. American Economic Review, 53(3), 433-444.

Orford, J., Herrington, M. \& Wood, E. (2004). Global Entrepreneurship Monitor 2004: South African Report [Online]

Available: http:www.gemconsortium.org/download/1283765427959/GEM\%20South\%20Africa\%202004.pdf [March 20, 2010].

Park, J., Lim, B. \& Koo, J. (2008). Developing the Capital Market To Widen and Diversify SMEs Financing: The Korean Experience. [Online]. Available: www.aseansec.org/22633-8.pdf [May 4, 2010].

Raosoft In (2010), Sample size calculator. [Online]. Available: http://www.raosoft.com/samplesize.html [May 11, 2010].

Rogerson C.M. (2008). Tracking SMME Development in South Africa: Issues of Finance, Training and the Regulatory Environment: Springer Science, Business Media pp 61-81.

Schoombee, A. (2000). Getting South African banks to serve micro-enterprises: An analysis of policy options. Development Southern Africa, 17(2), 751-767. doi:10.1080/713661429, http://dx.doi.org/10.1080/713661429

Scott, D.F. (1972). Evidence on the importance of financial structure. Journal on Financial Management,1(3), 45-60. doi:10.2307/3665143, http://dx.doi.org/10.2307/3665143

Shane, S. (2008). The importance of angel investing in financing the growth of entrepreneurial ventures. [online]. Available: http:// www.sba.gov/adw/research/banking.html [April 15, 2010]. 
Stiglitz, J. E. \& Weiss, A., (1981). Credit Rationing in Markets with Imperfect Information. American Economic Review 71, 393-419.

Umsobomvu Youth Fund (2008). Starting a business. [Online]. Available: http://www.youthportal.org.za [July 10, 2010].

Von Broembsen, M., Wood, E. \& Herrington, M. (2005). Global entrepreneurship monitor South Africa report. [Online]. Available: http://www.gsb.uct.ac.za/gsbwebb/userfiles/gem2005.pdf [November 15, 2010].

Table 1. Quantitative definition of SMEs in South Africa

\begin{tabular}{|l|l|l|l|}
\hline Type of firm & Employees & Turnover & Balance sheet \\
\hline Small & $1-49$ & Maximum R13m & Maximum R5m \\
\hline Medium & $51-200$ & Maximum R51m & Maximum R19m \\
\hline
\end{tabular}

Source: Government Gazette of the Republic of South Africa (2003).

Table 2. Correlations of awareness of BDS and success in getting financing

\begin{tabular}{|l|l|l|l|l|}
\hline Variable & Awareness of BDS & Non-awareness of BDS \\
\hline Use of BDS & R & p-value & R & p-value \\
\hline Access to finance-outcome & 0.743 & 0.0241 & -0.862 & 0.0013 \\
\hline
\end{tabular}

Table 3. Regression results of Awareness of BDS and access to finance outcome

\begin{tabular}{|c|c|c|c|c|}
\hline Model & $\mathrm{R}$ & R Square & $\begin{array}{ll}\text { Adjusted } & R \\
\text { Square } & \end{array}$ & $\begin{array}{l}\text { Std. Error of the } \\
\text { Estimate }\end{array}$ \\
\hline 1 & 0.946 & 0.963 & 0.951 & 0.426 \\
\hline
\end{tabular}

ANOVA
\begin{tabular}{|ll|l|l|l|l|l|}
\hline Model & Sum of Squares & Df & Mean Square & F & Sig. \\
\hline 1 & Regression & 0.344 & 3 & 0.344 & 0.426 & 0.000 \\
& Residual & 7.275 & 40 & 0.182 & & \\
\multicolumn{1}{|l|}{ Total } & 7.619 & 43 & & & \\
\hline
\end{tabular}

\begin{tabular}{|c|c|c|c|c|c|}
\hline \multicolumn{6}{|l|}{ Coefficients } \\
\hline \multirow[t]{3}{*}{ Model } & \multirow{2}{*}{\multicolumn{2}{|c|}{ Unstandardised Coefficients }} & Standardised & \multirow[b]{3}{*}{$\mathrm{T}$} & \multirow[b]{3}{*}{ Sig. } \\
\hline & & & & & \\
\hline & $\mathrm{B}$ & Std. Error & Beta & & \\
\hline 1 (Constant) & 1.388 & 0.280 & & 4.954 & 0.000 \\
\hline Awareness of BDS & 0.921 & 0.155 & 0.946 & 1.375 & 0.177 \\
\hline
\end{tabular}

**Dependent Variable: Access to finance outcome.

Table 4. Correlation of use of BDS and success in getting financing

\begin{tabular}{|l|l|l|l|l|}
\hline Variable & \multicolumn{2}{|l|}{ Use of BDS } & \multicolumn{2}{l|}{ Non-use of BDS } \\
\hline & $\mathrm{R}$ & $\mathrm{p}$-value & $\mathrm{R}$ & $\mathrm{p}$-value \\
\hline Access to finance-outcome & 0.841 & 0.0021 & -0.034 & 0.0124 \\
\hline
\end{tabular}

**Sig. 0.05 (2-tailed) 
Table 5. Regression results of Use of BDS and access to finance outcome

Model Summary

\begin{tabular}{|c|c|c|c|c|c|c|}
\hline \multicolumn{3}{|l|}{ Model } & $\mathrm{R}$ & R Square & Adjusted R Square & Std. Error of the Estimate \\
\hline & \multicolumn{2}{|l|}{1} & 0.841 & 0.839 & 0.830 & 0.426 \\
\hline \multicolumn{7}{|c|}{ ANOVA } \\
\hline \multicolumn{2}{|l|}{ Model } & Sum of Squares & Df & Mean Square & $\mathrm{F}$ & Sig. \\
\hline 1 & $\begin{array}{l}\text { Regression } \\
\text { Residual } \\
\text { Total }\end{array}$ & $\begin{array}{l}0.344 \\
7.275 \\
7.619\end{array}$ & $\begin{array}{l}6 \\
60 \\
66 \\
\end{array}$ & $\begin{array}{l}0.344 \\
0.182\end{array}$ & 0.356 & 0.000 \\
\hline
\end{tabular}

Coefficients

\begin{tabular}{|c|c|c|c|c|c|c|}
\hline \multirow[t]{2}{*}{ Model } & & \multicolumn{2}{|c|}{ Unstandardized Coefficients } & \multirow{2}{*}{$\begin{array}{l}\text { Standardized Coefficients } \\
\text { Beta }\end{array}$} & \multirow[b]{2}{*}{$\mathrm{T}$} & \multirow[b]{2}{*}{ P-value } \\
\hline & & $\mathrm{B}$ & Std. Error & & & \\
\hline \multirow[t]{2}{*}{1} & (Constant) & 1.388 & 0.280 & & 4.957 & 0.000 \\
\hline & Use of BDS & 0.973 & 0.155 & 0.841 & 1.375 & 0.001 \\
\hline
\end{tabular}

